\title{
Præsident Bushs \\ politiske orkan
}

Torben Krogh

\section{Efter katastrofen i New Orleans står den amerikanske præsident stærkt svækket, især inden- rigspolitisk, men også i forhold til resten af ver- den. Spørgsmålet er nu, hvilken kurs han vil vælge i et forsøg på at genvinde noget af den tabte ind- flydelse}

Når naturens kræfter slår voldsomt igennem, kalder det som regel på menneskeligt sammenhold ud over det sædvanlige. De nødstedte skal hjælpes, og katastrofens omfang skal så vidt muligt begrænses. Offentlige myndigheder, private organisationer og almindelige borgere går sammen om denne nødhjælpsindsats. Sådan tager billedet sig normalt ud, som vi senest så det, da tsunamien slog til ved Det Indiske Oceans kyster.

Anderledes forholdt det sig, da orkanen Katrina bevægede sig ind over de sydligste dele af Louisiana og Mississippi. Forfærdede fulgte amerikanerne orkanens hærgen, mens hjælpearbejdet var præget af langsommelighed, forvirring og fejldispositioner. En af USA's mest særegne byer, New Orleans, måtte evakueres, da digerne, der indtil da havde beskyttet byen, brød sammen. Under totalt kaotiske forhold flygtede de beboere, der kunne, fra byen. Men nogle kunne ikke flygte ved egen hjælp. De måtte blive tilbage, og mange led enten drukne- eller sultedøden

Det skete midt i verdens mægtigste land, økonomisk såvel som militært. Amerikanernes forfærdelse over katastrofens omfang blev hurtigt blandet med skam og vrede, og harmen samlede sig ikke mindst om præsident George W. Bush. Han og hans regering undervurderede i første omgang helt og aldeles, hvad der var sket i New Orleans. Fra den mandag, orkanen ramte sydkysten, 
til fredag samme uge kom der så godt som ingen hjælp fra Washington. Præsidenten selv tog til Californien for at holde en tale om Irak.

Den direkte ansvarlige for at sætte en hurtig hjælpeaktion i gang var Federal Emergency Management Agency (FEMA). Men denne institution levede helt og holdent op til sit omdømme som et dårligt fungerende bureaukrati. Ikke desto mindre overøste Bush direktøren for FEMA, Michael Brown, med rosende ord, og det til trods for at Brown havde indrømmet, at han først med tre dages forsinkelse havde hørt om de mange tusinde flygtninge i New Orleans Convention Center.

Brown gjorde sig også bemærket med en udtalelse om, at ingen havde forudset, at digerne ville bryde sammen. Rent faktisk har advarslerne i de senere år været mangfoldige.

\section{Forbindelsen med Irak}

De politiske konsekvenser for Bush rækker imidlertid langt videre end den umiddelbare vrede $o g$ foragt over hans regerings inkompetente håndtering af katastrofesituationen. På en lang række områder vil følgerne slå igennem i form af voksende problemer for præsidenten med at få sin politik igennem. Samtidig står USA svækket på den internationale scene. Som flere amerikanske iagttagere har fremhævet, vil den selvbestaltede rolle som vejleder i demokrati og god regeringsførelse i lang tid være svækket. De, der bliver udsat for sådanne belæringer eller bebrejdelser for ikke at leve op til de amerikanske krav, kan nu svare med et enkelt ord: Katrina.

At det netop var Irak, der stod på præsidentens dagsorden under besøget i Californien, fik en særlig symbolsk betydning. En af årsagerne til, at hjælpearbejdet gik så langsomt i New Orleans, var fraværet af et stort antal soldater fra Louisianas nationalgarde. De var væk, fordi de gør tjeneste i Irak. Dette forhold er blevet brugt flittigt af de kritikere, der mener, at Bush-regeringen har ladet krigen og besættelsen dræne det amerikanske samfund for alt for mange ressourcer. I den forbindelse er de utilstrækkelige diger også blevet fremhævet. Gentagne gange har de lokale myndigheder og eksperter i digebyggeri stillet krav om at få dem forstærket. Men det har der ikke været penge til i forbundsregeringens budget.

Men mon ikke der havde været det, hvis det i stedet var Florida, der havde presset på? Det er et af de mange retoriske og ubehagelige spørgsmål, der er blevet rejst i den amerikanske debat. Ikke blot har præsidentens bror igennem en årrække været guvernør i denne stat. Florida er også hjemsted for et stort antal velstående - og helt overvejende hvide - pensionister. Den befolkningsgruppe har nemmere ved at vinde Bush-administrationens velvillige opmærksomhed end de 
fattige sorte i Louisiana. I den helt kyniske udgave er det blevet påpeget, at de fattige sorte jo ikke er meget værd som vælgere, set fra Republikanernes synsvinkel. De fleste stemmer slet ikke, og det store flertal af dem, der gør det, sætter deres kryds ved Demokraterne.

\section{Fattigdom og underskud}

Imidlertid er det ikke nødvendigt at tillægge Bush en sådan kynisme for at konstatere den kendsgerning, at de store sociale skel i USA er blevet yderligere øget $i$ hans embedsperiode. Få dage før orkanen meddelte USA's statistiske departement, the Census Bureau, at fattigdommen voksede i løbet af 2004 med yderligere 1,1 million borgere. Efter at være faldet markant under præsident Bill Clinton er antallet af fattige amerikanere steget med 17 procent.

En anden væsentlig indikator på udviklingen under Bush er væksten i spædbørnsdødelighed. Den havde ellers været konstant faldende lige siden 1958. Men ifølge CIA's World Factbook er USA nu nede på en placering som nummer 43 i verden. Et par sammenligninger kan være illustrerende: Børnedødeligheden i Washington D.C. er mere en dobbelt så høj som i Beijing. Og et afroamerikansk spædbarn har statistisk set større risiko for at dø end spædbørn i byerne i den indiske delstat Kerala.

Katastrofen i New Orleans har in- spireret amerikanske kommentatorer og analytikere til at fremdrage oplysninger af denne karakter. De store sociale uligheder, der er forstærket i George W. Bushs små fem år ved magten, er blevet sat i fokus. Og de er blevet stillet i kontrast til de omfattende skattelettelser, præsidenten forsøger at få igennem Kongressen. De vil i alt væsentligt komme de højere indkomstgrupper til gavn. Men efter orkanens hærgen er selv en del republikanske lovgivere blevet særdeles skeptiske.

Det er de ikke mindst, fordi en enorm regning er på vej for at dække udgifterne til genopbygningen i Louisiana og Mississippi. Bush har allerede bedt Kongressen om at bevilge 51,8 milliarder dollars. Men regeringen har under hånden fortalt republikanske kongresmedlemmer, at de samlede udgifter meget vel kan løbe op i 100 mia. dollars. Med et sådant træk på den føderale kasse, vil der næppe være plads til skattelettelser. De fortsatte og forstærkede problemer i Irak lægger samtidig beslag på store bevillinger. $\mathrm{Og}$ den økonomiske sagkundskab siger nogenlunde enstemmigt, at den amerikanske regering ikke vedvarende kan arbejde med så store underskud, som det har været tilfældet i de senere år.

\section{Skeptiske republikanere}

Et yderligere problem for Bush består $\mathrm{i}$, at finansieringen af de plan- 
lagte skattelettelser skulle bestå i en lang række nedskæringer på offentlige ydelser - lige fra medicintilskud til studenterlån. De samlede besparelser skulle udgøre 70 mia. dollars. Ganske ubestrideligt er der med denne plan tale om at overføre ressourcer fra de mindre velstillede amerikanere til de højere indtægtsgrupper. Denne form for fordelingspolitik vil efter orkanen Katrina blive mødt med større modstand end tidligere.

I en sådan situation er Det Hvide Hus stærkt afhængig af det, der i den politiske jargon kaldes "præsidentens armvridning”. Den består i, at præsidenten lægger hele sin autoritet ind i forsøget på at overtale et kongresflertal til at støtte hans politik. Men for Bush består det store problem netop i, at hans autoritet er helt i bund. Reaktionerne på orkanen blotlagde store mangler i hans lederevner. I meningsmålingerne har han aldrig stået dårligere. $\mathrm{Og}$ dertil kommer, at politikerne så småt er begyndt at tænke på tiden efter Bush, da han ikke selv skal på valg igen.

Det skal alle medlemmerne af Repræsentanternes Hus og en tredjedel af senatorerne til gengæld om godt et års tid. Og som sagerne står nu, vil det også for mange republikanere være en uklog taktik at fremstå som alt for tæt allieret med præsidenten. En vis distance vil kunne betale sig.

\section{Slaget mod USA's omdømme}

Men det er ikke kun i den hjemlige politik, Bush har mistet autoritet. Det samme gælder i forholdet til resten af verden. Her stod han i forvejen meget dårligt i den europæiske opinion. Den 31. august offentliggjorde German Marshall Fund of the United States et studie under titlen "Transatlantic Trends".

Det viste, at 72 procent af europæerne i ti forskellige lande misbilliger Bushs håndtering af internationale anliggender. Fondens formand, Craig Kennedy, sagde ved rapportens offentliggørelse, at der "til trods for stærke bestræbelser på at udbedre forholdet, stadig er en forskel på, hvordan vi ser på hinanden og på verden".

Denne vurdering blev uddybet af en tysk politisk analytiker, Richard Hilmer. Han sagde, at tyskerne er blevet chokeret over begivenhederne i New Orleans, og at de "nu føler sig bekræftet i deres støtte til vores sociale solidaritet og spørger, om dette virkelig er, hvad der kommer ud af den amerikanske økonomiske model”. Han tilføjede, at den kendsgerning, at Bush er upopulær i brede kredse, har forstærket disse kritiske spørgsmal.

Philip Gordon fra Brookings Institute i Washington opsummerede, hvad New Orleans-katastrofen har betydet for det globale syn på USA: "Vi har fortalt mennesker rundt omkring i verden, hvordan de skal styre et de- 
mokrati og det civile samfund. Og nu har vi fået de blodige indvolde $\mathrm{i}$ vores samfund - dets lidende underklasse, hvor mange knapt er i stand til at læse og skrive - afsløret for verden. Det er et nyt frygteligt slag mod vores omdømme."

\section{Bureaukrati og forvirring}

Den stærkt kritiske holdning til George W. Bush hindrede imidlertid ikke, at tilbuddene om hurtig hjælp til USA strømmede ind. De kom fra EU som sådan, fra mange af de enkelte EU-lande, fra andre europæiske nationer og såmænd også fra u-lande som Venezuela og Cuba.

Men her fik USA's omdømme en ny ridse. Det amerikanske udenrigsministerium bad i weekenden efter katastrofen om hurtig nødhjælp via NATO, FN og EU. Flere lande reagerede omgående, men måtte så konstatere, at amerikanerne ikke var rede til at modtage de leverancer, der stod og ventede i transportfly på europæiske flyvepladser.

Sverige var et af de lande, der havde en sådan oplevelse. Så snart den amerikanske anmodning indløb, gik svenskerne i gang med at laste et Hercules-fly med vandrensningsanlæg, krisegeneratorer og komponenter til et midlertidigt mobilnetværk. Denne leverance var parat til afgang allerede lørdag. Men endnu den følgende onsdag stod flyet på landingsbanen i Sverige.

Det svenske udenrigsministerium oplyste, at USA havde udtrykt taknemmelighed over den hurtige reaktion. Men så havde amerikanerne tilføjet, at "de var nødt til at koordinere og fremlægge en prioriteret liste". Andre europæiske lande måtte også vente i dagevis på at levere alt fra avancerede vandpumper til telte og tæpper.

Udenrigsministeriet i Washington var tydeligt nok ubehageligt berørt over denne situation. Men det meldte hus forbi ved at understrege, at det kun virkede som mellemmand for FEMA. Ministeriet videregav de lister, det fik fra FEMA, og de blev ændret hver eneste dag.

FEMA havde en anden version. Departementets medarbejdere i katastrofeområdet blev informeret om de tilbud, der kom ind fra de udenlandske donorer. Når et tilbud kunne imødekomme et lokalt behov, ville Udenrigsministeriet sørge for at få den pågældende leverance fra giverlandet. At tidsfaktoren i denne forbindelse kunne være af afgørende betydning, indgik øjensynlig ikke i FEMAs overvejelser over den mest hensigtsmæssige fremgangsmade.

De forskellige forklaringer fra de amerikanske myndigheder bekræftede i hvert fald de involverede europæere i deres opfattelse af, at USA åbenbart var ganske uforberedt på at håndtere en katastrofe som Katrinas hærgen i og omkring New Orleans. Bureaukratiske forviklinger og kompetencestridigheder førte til langsom og usikker sagsbehandling. 
Den sendrægtige modtagelse af den udenlandske nødhjælp blev endnu et tegn på, at ledelsen fra Det Hvide Hus var præget af inkompetence og forvirring.

\section{Mere protektionisme?}

Når den foreløbige status skal gøres op rent politisk, må det konstateres, at George W. Bush og hans administration har lidt et alvorligt, men selvforskyldt troværdighedstab. Spørgsmålet er nu, hvordan han vil reagere i sine forsøg på at genvinde noget af det tabte. Og her hersker der vidt forskellige opfattelser blandt de amerikanske iagttagere.

Indenrigspolitisk står præsidenten foran en række barske realiteter. Katastrofen vil trække lange økonomiske spor, både i de offentlige budgetter og i samfundsøkonomien i bredere forstand. Som tidligere nævnt er det svært at se, hvordan der stadig kan være plads til de meget omtalte skattelettelser. Men dertil skal lægges stigende benzinpriser og andre problemer for transporten.

Eksempelvis får mange landmænd i Midtvesten normalt transporteret deres afgrøder med fragtskibe ned ad Mississippi-floden til New Orleans, hvorfra majsen, hveden og soyabønnerne bliver sendt videre til eksportmarkederne. Imidlertid blev havnen i New Orleans alvorligt beskadiget af orkanen, og da høsten blev kørt ind oppe nordpå, var det stadig meget usikkert, hvornår havnens faciliteter ville blive genetableret fuldt ud.

Det kan umiddelbart lyde som et mere perifert problem i forhold til mange andre konsekvenser af orkanen. Men de problemer, landmændene nu er blevet påført, vil øge deres politiske pres for at bevare de nuværende subsidier.

Bush-administrationen havde ellers indstillet sig på, at landbrugsstøtten må skæres ned. Landbrugsminister Mike Johanns har for nylig været på en større rejse rundt i landet for at fortælle de amerikanske landmænd, at det i fremtiden bliver nødvendigt at reducere subsidierne ganske betydeligt. De beløb sig sidste år til 47 milliarder dollars. Mike Johanns begrundede de planlagte nedskæringer med behovet for at indgå internationale aftaler, der kan åbne nye eksportmarkeder for det amerikanske landbrug, da også andre velstående lande - først og fremmest EU - i så fald vil være forpligtet til at afvikle deres subsidier.

Men interessant nok henviste landbrugsministeren også til nødvendigheden af at overholde internationale aftaler om frihandel. Traditionelt har USA inden for Verdenshandelsorganisationen WTO presset på for at få stadig flere handelsområder liberaliseret. Men i to omgange er forhandlingerne inden for WTO brudt sammen, ikke mindst på grund af uenighed om landbrugsstøtten. De samlede sub- 
sidier, som ikke mindst udviklingslandene kræver afskaffet, beløber sig årligt til 280 mia. dollars. Ikke blot USA, men også EU er i den senere tid blevet mere imødekommende over for tanken om at ophæve dem - eller i hvert fald reducere dem markant.

Efter orkanen er det tvivlsomt, om Bush-administrationen vil - eller kan - gå videre ad denne vej. Presset for at få gennemført en mere protektionistisk handelspolitik vil efter alt at dømme blive kraftigt. Dette pres kommer fra mange forskellige brancher, og stemningen for en mere selvbeskyttende politik i traditionel forstand kan meget vel vise sig at være stigende. Derfor kan USA blive en endnu mere besværlig forhandlingspartner i WTO.

\section{To mulige veje}

Spørgsmålet er i det hele taget, hvilken vej de amerikanske ledere vil vælge i dette krydsfelt mellem indenrigs- og udenrigspolitik. Indenrigspolitisk står Bush fundamentalt over for valget mellem to vidt forskellige linjer. Han kan i lyset af de dårlige meningsmålinger og den åbenlyse utilfredshed med hans ledelse - der vel at mærke rækker langt ind i konservative kredse - forsøge at konsolidere sig i forhold til sine kernevælgere. Højrerepublikanske mærkesager vil komme endnu højere op på hans dagsorden. I givet fald vil der især blive tale om holdnings- prægede emner som fx dødsstraf, abortforbud og undervisning i den bibelske skabelsesberetning.

Men han kan også - som nogle konservative skribenter faktisk har anbefalet - lancere et omfattende program til bekæmpelse af fattigdommen. Sådanne programmer har USA tidligere haft, og selv om det så langt fra har ført til afskaffelse af al fattigdom, er dens omfang dog i perioder blevet formindsket. Efter orkanen står det som en skamplet over Bush, at den i hans embedstid er vokset markant. Langt ind i hans egne rækker har der bredt sig en erkendelse af, at han - og dermed deres eget parti - ikke kan holde til at fremstå som den præsident og det parti, der ikke bekymrer sig alvorligt over de fattige amerikaneres lod.

Uanset om den ene eller anden vej bliver valgt, kan den meget vel blive ledsaget af en mere nationalistisk og selvtilstrækkelig politik. Hvis resten af verden ser med mistro på USA, er det samme i stigende grad tilfældet for amerikanerne i forhold til resten af verden. Det er en udvikling, Bush-administrationen med stærke personligheder som vicepræsident Dick Cheney og forsvarsminister Donald Rumsfeld i høj grad har befordret. I deres udenrigspolitik har det været en gennemgående linje, at de ikke vil gå ind i forpligtende internationale aftaler, der på nogen måde begrænser deres egen handlefrihed. Som det er fremgået af Bob Woodwards fremra- 
gender bøger om optakten til krigene i Afghanistan og Irak, så mener de, at det er deres soleklare prærogativ som ledere i verdens eneste supermagt.

\section{Håb om kursændring}

Hvad de har fejlvurderet er måske både den animositet, denne udøvelse af magtens arrogance har udløst i store dele af verden, og den begrænsning, der faktisk har vist sig at være i selv USA's militære formåen. Da de amerikanske ledere forsøgte at samle en stor koalition bag krigen imod Saddam Husseins Irak, løb de ind i så mange afvisninger - også fra normalt venligtsindede lande - at det burde have rejst store advarselssignaler. Men krigen var besluttet, og derfor blev dette problem skudt til side som noget sekundært.

Det samme skete med de advarsler, der blev fremsat internt over for præsidenten og hans nærmeste meningsfæller i denne sag. De gik lige præcis på den situation, der nu har udviklet sig. Bush indledte krigen uden nogen klar strategi for en senere tilbagetrækning, selv om der var almindelig enighed om, at USA hverken skulle være besættelsesmagt eller såkaldt "nation builder". Det er ikke desto mindre, hvad der er sket $\mathrm{i}$ løbet af de sidste par år, og det har tæret hårdt på både de mandskabsmæssige og de økonomiske ressourcer. Hvis USA rådede over tilstrækkeligt mange professionelle og toptrænede soldater, ville der ikke i dag have været delinger i Irak fra Louisianas nationalgarde.

Ikke mindst blandt europæiske regeringer er der nu forhåbninger om, at de store vanskeligheder i Irak og de frygtelige følger af orkanen Katrinas hærgen kan føre til et sporskifte, når det gælder Bush-regeringens holdning til internationalt samarbejde. Forudsætningen er, at ledelsen i Washington nu må have indset, at den ikke fortsat kan føre udenrigs- og sikkerhedspolitik under slagordet om, at "de, der ikke er med os, er imod os". Verden er for kompliceret til at anvende en sådan skillelinje.

Skal denne erkendelse brede sig i Bush-administrationen og omsættes i handling, forudsætter det imidlertid, at katastrofen i New Orleans fører til en markant ændring i de holdninger, der hidtil har ligget til grund for dens politik. Det vil imidlertid være det samme som at indrømme, at han hidtil har ført en fejlslagen politik. Og en sådan ydmyghed har indtil nu ikke været noget fremherskende træk i George W. Bushs udøvelse af præsidentembedet. 